\title{
Library Media Center School Reading Programs at Morrisville Year-Round Elementary School
}

\author{
by Nancy B. McNitt
}

H ow do you develop a lifelong relationship with books? READ! Getting books into children's hands and providing motivational activities to promote reading help develop a joy of reading. At Morrisville Year-Round Elementary School, reading success is nourished by daily reading to children, daily sustained silent reading, and weekly at-home reading expectations.

The library media center supports this school literacy initiative. A strong, effective, growing book collection is in place. Careful book selection is continual. The unofficial library media center mission statement is "a book on the library shelf is a book not being read!"

The school community has continual flexible access to library media center materials. Some of the ways library media coordinators connect the 1,010 students with books include leading author studies, booktalking, teaching information skills with a wide variety of books, and connecting books to individual readers. Staff check out books for room use to support teaching themes, to meet the needs of special readers, for read-alouds, and for other curriculum uses. Families are encouraged to check out books for preschoolers, for older siblings, and for parent education.

To further motivate reading, the LMC staff leads three allschool reading celebrations. A fall readathon challenges students to read 15,000 pages in three weeks. The library media center provides forms for students and staff to record the number of "pages read" at school and at home. Volunteers graph reading success in the halls, which helps motivate sustained reading. Administrators, who will perform for reading awards. daily encourage reading. Morrisville readers have enjoyed their administrators riding bicycle laps in school, sitting on the school roof, and handcuffed (with our DARE police officer present) to a flagpole. This year the principal donned pajamas, curlers, and a night hat, and reclined in a hallway bed to read aloud to all classes. Knowing that teachers would make certain that 100 percent of the student body would participate in this event, the PTA took charge of this year's readathon and gave reading shirts to each child.

In spring, after daylight-saving time begins, the library media center staff delivers an annual Morrisville Reader challenge to all students and staff. Each person who reads seven hours at home, before school ends, receives a Morrisville Reader button. A child who spends six years at Morrisville could have six different colored reading buttons when leaving for middle school.

Planning for the reading challenge begins in early March. LMC staff members meet with staff committees and grade level planning teams to set spring reading goals. Dates to start and conclude the challenge are set on the all-school calendar.

The library media center sends parents a letter describing the challenge. On the back of the letter is a thirty-space chart with two spaces marked "free" (twenty-eight spaces = seven hours). The reader crosses out one space each time he reads fifteen minutes. Reading can be someone reading to the reader, the reader reading to someone, or the reader reading silently. Any kind of reading counts - comic books, computer monitor, newspapers, books, - the goal is to READ.

Teachers, administrators, and library media coordinators support the ongoing challenge. The library media center staff displays the reading button and provides new sheets as originals are lost. Teachers put reminder notes in newsletters. Administrators add updates about the ongoing challenge during morning announcements.

Close to 75 percent of Morrisville Readers, staff and students, receive their reading buttons on the Friday school television news. Teachers have students bring their parent-signed, completed reading chart to the library media center. On-air, each reader tells his name and exchanges the chart for a reading button. Reading motivation shoots upward as soon as the first buttons are handed out! Before school television, photographs of Morrisville Readers were displayed in the school hall.

Continuing to support the importance of books and reading, the library media center leads an end-of-year all-school book swap. Media staff and parents collect used books in good condition throughout the year, so each swap begins with and ends with hundreds of extra books. In June, students bring up to eight used books to school. Volunteers count and sort books and write on a studentand teacher-labeled plastic bag how many books the student can get. On swap day, scheduled classes beginning with fifth graders bring their labeled empty bags to the library media center and choose recycled books. About 70 percent of the students take part in the swap. On the day after the swap, each student who chose not to join the swap can choose one of the remaining books.

The library media center also manages the Accelerated Reader computer reading management program. Students can read one of more than 2,300 books and then test themselves on their understanding of the book. Book lists are kept in the library media center, by the classroom computer, at the local public libraries, and at area book stores. In this school year about 760 students successfully read over 18,000 books.

Other all-school initiatives are ongoing. The school is enrolled in Count on Reading. Students read and vote for the North Carolina Children's Book Award nominees. Many classrooms participate in the Pizza Hut Book-It program. All classrooms have room libraries supported by the library media center. A yearly library media center book fair and teacher-provided opportunities to buy books from publishers' book clubs encourage student libraries. At the beginning of the school year, the library media coordinators help students get their public library cards, and they support continual use of the public library.

The library media center supports literacy year-round. Library media coordinators connect students and books daily using a wide breadth of titles students want to read (yes, this means some series books like "Goosebumps"). Throughout the school year, the library media center staff leads motivating activities that encourage ongoing reading. The outcome of all these initiatives is wonderful readers who believe books are important! 